\title{
Development and validation of qualitative SYBR®Green Real-Time PCR for detection and discrimination of Listeria spp. and Listeria monocytogenes
}

\author{
Elodie Barbau-Piednoir • Nadine Botteldoorn • \\ Marc Yde • Jacques Mahillon • Nancy H. Roosens
}

Received: 6 June 2012 / Revised: 26 September 2012 / Accepted: 29 September 2012 / Published online: 20 October 2012

(C) The Author(s) 2012. This article is published with open access at Springerlink.com

\begin{abstract}
A combination of four qualitative SYBR ${ }^{\circledR}$ Green qPCR screening assays targeting two levels of discrimination: Listeria genus (except Listeria grayi) and Listeria monocytogenes, is presented. These assays have been developed to be run simultaneously using the same polymerase chain reaction (PCR) programme. The paper also proposes a new validation procedure to specifically validate qPCR assays applied to food microbiology according to two guidelines: the ISO 22118 norm and the "Definition of minimum performance requirements for analytical methods of GMO testing". The developed assays target the iap, prs and $h l y A$ genes that belong to or neighbour the virulence cluster of Listeria spp. The selected primers were designed to amplify short fragments (60 to $103 \mathrm{bp}$ ) in order to obtain optimal PCR efficiency (between 97 and $107 \%$ efficiency). The limit of detection of the SYBR ${ }^{\circledR}$ Green qPCR assays is two to five copies of target genes per qPCR reaction. These
\end{abstract}

Nadine Botteldoorn and Nancy H. Roosens have equally contributed to this work.

E. Barbau-Piednoir $\cdot$ N. Botteldoorn $(\bowtie) \cdot$ M. Yde

N. H. Roosens

Scientific Institute of Public Health,

J. Wytsmanstraat 14,

1050 Brussels, Belgium

e-mail: nadine.botteldoorn@wiv-isp.be

E. Barbau-Piednoir

e-mail: epiednoir@wiv-isp.be

E. Barbau-Piednoir $\cdot$ J. Mahillon

Faculty of Bioscience Engineering,

Earth and Life Institute, Université Catholique de Louvain,

Croix du Sud 2, bte L7.05.12,

1348 Louvain-la-Neuve, Belgium assays are highly accurate (98.08 and $100 \%$ accuracy for the Listeria spp. and L. monocytogenes assays, respectively).

Keywords Real-time PCR · SYBR ${ }^{\circledR}$ Green · Foodborne pathogens $\cdot$ Detection $\cdot$ Listeria $\cdot \mathrm{qPCR}$ validation

\section{Introduction}

Listeria are small Gram-positive bacilli, ubiquitous, nonsporeforming, facultative anaerobic bacteria that grow between -2 and $50{ }^{\circ} \mathrm{C}$, with optimal growth between 30 and $37{ }^{\circ} \mathrm{C}$ (Bajard et al. 1996; Farber and Peterkin 1991). The Listeria genus officially includes six species: Listeria monocytogenes, Listeria ivanovii, Listeria innocua, Listeria seeligeri, Listeria welshimeri, Listeria grayi (Garrity et al. 2004). Two other species, Listeria marthii (close to L. monocytogenes and L. innocua) and Listeria rocourtiae (close to $L$. grayi), have recently been described (Graves et al. 2010 and Leclercq et al. 2010) but have not yet been introduced into the official classification (Garrity et al. 2004). Among those, L. monocytogenes is the most reported as pathogenic for humans (listeriosis) (McLauchlin et al. 2004). However, some cases of listeriosis have also been attributed to $L$. ivanovii (Cummins et al. 1994; Guillet et al. 2010; Lessing et al. 1994), L. innocua (Perrin et al. 2003) and L. seeligeri (Rocourt et al. 1986).

L. monocytogenes has a low annual incidence in Europe, with about 1,500 cases per year (Anonymous 2011a), but with its high fatality rate listeriosis ranks among the most frequent cause of human death due to foodborne illnesses (Cardoen et al. 2009; de Valk 2005). Foodborne listeriosis mainly affects a specific group of the population with 
increased susceptibility: the YOPI (young, old, pregnant and immunodepressed) (Anonymous 2001). Hence, due to ageing of the population, control of Listeria spp. is becoming an increasingly important issue.

Listeriosis cases are associated with the consumption of raw food products (Berrada et al. 2006; Tham et al. 2000; Inoue et al. 2000; Rocourt et al. 2000; de Valk 2001; Inoue et al. 2000), ready-to-eat food (de Valk 2001) and post-processing contaminated food (Maijala et al. 2001; Makino et al. 2005; Norrung et al. 1999). The ability of Listeria spp. to grow at low temperatures increases the risk of infection. International standards exist for the detection and enumeration of $L$. monocytogenes in food and feed (Anonymous 1996a; Anonymous 1996b). These methods are time consuming (at least 5 days) and labour intensive. In order to quickly identify the source of foodborne outbreaks or for a faster commercial batch release, tools for rapid detection and identification of pathogens in food have been developed. The majority of these assays are limited to the specific detection of L. monocytogenes. They are classical PCR assays (Amagliani et al. 2004; Jung et al. 2003; Li et al. 2000; Liu et al. 2004; Mukhopadhyay and Mukhopadhyay 2007; Winters et al. 1999), reverse-transcription PCR (RTPCR) (Klein and Juneja 1997) and, more recently, real-time PCR (qPCR) using mainly the TaqMan ${ }^{\circledR}$ technology (Hough et al. 2002; O'Grady et al. 2008; Oravcova et al. 2007; Rossmanith et al. 2006; Rudi et al. 2005). They are targeting genes such as iap, prfA and hlyA involved in L. monocytogenes pathogenicity (Dussurget et al. 2004) and are therefore specific for this species.

In this paper, we propose a new detection system that facilitates a rational detection of pathogenic bacteria using as study case the Listeria genus, considered as one of the most important of foodborne pathogens transmitted by food and water (Cardoen et al. 2009; Anonymous 2011b). The Combinatory SYBR ${ }^{\circledR}$ Green qPCR screening for foodborne pathogens (CoSYPS Path Food) is based on two detection levels. A first set of generic assays allows the detection of the presence of all bacteria belonging to the Listeria genus. A second set of assays allows the specific detection of $L$. monocytogenes. The four primer pairs were chosen in order to perform at the same PCR conditions, allowing the different assays to be performed as four simplex assays simultaneously, on the same plate. Moreover, as there is no official method to validate a $\mathrm{qPCR}$ assay applied to food microbiology, a guideline to validate food microbiology qPCR assay based on the ISO 22118 norm (Anonymous 2011b) and the "Definition of minimum performance requirements for analyticals methods of GMO testing" (Anonymous 2008a) is also proposed. The four SYBR ${ }^{\circledR} \mathrm{Green}$ qPCR assays developed in this study were evaluated for selectivity, sensitivity, dynamic range, PCR efficiencies, repeatability and reproducibility. The advantages of the CoSYPS Path Food screening strategy and the validation guideline are discussed.

\section{Materials and methods}

\section{Bacterial strains}

The bacterial strains used in this study are listed in Table 1 . A panel of 128 bacterial, two mold, two yeast and two virus strains has been used. The strains were obtained from the National Reference Centres and Laboratories.

Bacterial growth conditions, DNA extraction and DNA quantification

Overnight cultures of each bacterial strain were grown in liquid brain-heart infusion or Bolton liquid medium (for Campylobacter) at adequate temperature and oxygen conditions. The total DNA from each strain was extracted with the DNeasy Blood and Tissue Kit (Qiagen). Genomic DNA (gDNA) from yeast and fungal were extracted using the Invisorb Spin Plant Mini Kit (STRATEC Molecular GmbH) and ZR Fungal/Bacterial gDNA extraction (Zymo Research), respectively. Viral RNA was extracted using the RNeasy mini kit (Qiagen) and cDNA was obtained by reverse transcription using the Transcriptor high-fidelity cDNA synthesis kit (Roche). cDNA amplification was checked with a specific PCR amplification. All kits were used according to the manufacturer's recommendations. DNA quality was controlled on agarose gel and DNA concentration was measured using a Nanodrop ${ }^{\circledR} 2000$ device according to the manufacturer's recommendations.

\section{Development and in silico assessment of primer pairs}

A uniform primer design approach was applied in the development of all primer pairs. The first step consisted of collecting a set of genes of potential interest, either genus or species specific (Glaser et al. 2001; Hough et al. 2002; Kerouanton et al. 2009; Liu et al. 2004; McLauchlin et al. 2004; O'Grady et al. 2008; Oravcova et al. 2007; Pan and Breidt 2007). The second step included the collection of DNA sequences relevant for the selected targets from the NCBI public database (http://www.ncbi.nlm.nih.gov/sites/entrez). The primer pairs were designed, preferentially within conserved regions, using the "Primer 3" programme (http://frodo.wi.mit.edu/primer3/) (Rozen and Skaletsky 2000) with the "product size range" specification set at "60 to $120 \mathrm{bp"} \mathrm{and}$ "primer size" optimal set at " 22 bases". An in silico test of the primer pairs' selectivity was then performed. This test consisted of a bioinformatical analysis carried out with the "wprimersearch" software (https://wemboss.uio.no/wEMBOSS/) (Rice et al. 2000; Sarachu and Colet 2005), which mimics the PCR amplification of the tested primers on a database of bacterial genome sequences from NCBI of 217 bacteria, representing 103 species belonging to 61 genera. Only primer 
Table 1 Selectivity assessment of the four SYBR ${ }^{\circledR}$ Green qPCR assays: "iap-50-deg", "prs-2-deg", "hlyA-177” and "hlyA-146-deg-tronc"

\begin{tabular}{|c|c|c|c|c|c|c|c|c|c|}
\hline Genus & Species & Serogroup & GRAM & Origin & Reference & $\begin{array}{l}\text { iap- } \\
50-\text { deg }\end{array}$ & $\begin{array}{l}\text { prs- } \\
2-\operatorname{deg}\end{array}$ & $\begin{array}{l}\text { hlyA- } \\
177\end{array}$ & $\begin{array}{l}\text { hlyA-146- } \\
\text { deg-tronc }\end{array}$ \\
\hline Listeria & monocytogenes & $1 / 2 \mathrm{a}$ & + & List-NRC & $10 / 13$ & + & + & + & + \\
\hline Listeria & monocytogenes & $1 / 2 \mathrm{a}$ & + & List-NRC & $10 / 14$ & + & + & + & + \\
\hline Listeria & monocytogenes & $1 / 2 \mathrm{a}$ & + & List-NRC & $10 / 15$ & nt & nt & + & + \\
\hline Listeria & monocytogenes & $1 / 2 \mathrm{a}$ & + & List-NRC & $10 / 20$ & nt & nt & + & + \\
\hline Listeria & monocytogenes & $1 / 2 \mathrm{a}$ & + & List-NRC & $10 / 21$ & nt & $\mathrm{nt}$ & + & + \\
\hline Listeria & monocytogenes & $1 / 2 \mathrm{a}$ & + & List-NRC & $10 / 22$ & nt & $\mathrm{nt}$ & + & + \\
\hline Listeria & monocytogenes & $1 / 2 \mathrm{a}$ & + & List-NRC & $10 / 23$ & $\mathrm{nt}$ & nt & + & + \\
\hline Listeria & monocytogenes & $1 / 2 \mathrm{a}$ & + & List-NRC & ATCC 51772 & + & + & + & + \\
\hline Listeria & monocytogenes & $1 / 2 b$ & + & List-NRC & ATCC 51777 & + & + & + & + \\
\hline Listeria & monocytogenes & $1 / 2 b$ & + & List-NRC & $10 / 2$ & + & + & + & + \\
\hline Listeria & monocytogenes & $1 / 2 b$ & + & List-NRC & $10 / 28$ & + & + & + & + \\
\hline Listeria & monocytogenes & $1 / 2 b$ & + & List-NRC & $10 / 50$ & $\mathrm{nt}$ & $\mathrm{nt}$ & + & + \\
\hline Listeria & monocytogenes & $1 / 2 b$ & + & List-NRC & $10 / 68$ & nt & $\mathrm{nt}$ & + & + \\
\hline Listeria & monocytogenes & $1 / 2 b$ & + & List-NRC & $10 / 109$ & $\mathrm{nt}$ & $\mathrm{nt}$ & + & + \\
\hline Listeria & monocytogenes & $1 / 2 \mathrm{c}$ & + & List-NRC & $10 / 48$ & + & + & + & + \\
\hline Listeria & monocytogenes & $1 / 2 \mathrm{c}$ & + & List-NRC & $10 / 16$ & nt & $\mathrm{nt}$ & + & + \\
\hline Listeria & monocytogenes & $1 / 2 \mathrm{c}$ & + & List-NRC & $10 / 49$ & $\mathrm{nt}$ & $\mathrm{nt}$ & + & + \\
\hline Listeria & monocytogenes & $1 / 2 c$ & + & List-NRC & $10 / 58$ & nt & nt & + & + \\
\hline Listeria & monocytogenes & $1 / 2 \mathrm{c}$ & + & List-NRC & $10 / 153$ & nt & nt & + & + \\
\hline Listeria & monocytogenes & $1 / 2 \mathrm{c}$ & + & List-NRC & $10 / 160$ & $\mathrm{nt}$ & $\mathrm{nt}$ & + & + \\
\hline Listeria & monocytogenes & $1 / 2 \mathrm{c}$ & + & List-NRC & $10 / 184$ & $\mathrm{nt}$ & $\mathrm{nt}$ & + & + \\
\hline Listeria & monocytogenes & $1 / 2 \mathrm{c}$ & + & List-NRC & $10 / 192$ & $\mathrm{nt}$ & nt & + & + \\
\hline Listeria & monocytogenes & $3 a$ & + & List-NRC & $10 / 29$ & + & + & + & + \\
\hline Listeria & monocytogenes & $3 a$ & + & List-NRC & $10 / 202$ & $\mathrm{nt}$ & nt & + & + \\
\hline Listeria & monocytogenes & $3 a$ & + & List-NRC & $10 / 237$ & nt & $\mathrm{nt}$ & + & + \\
\hline Listeria & monocytogenes & $3 a$ & + & List-NRC & $9 / 109$ & nt & nt & + & + \\
\hline Listeria & monocytogenes & $3 a$ & + & List-NRC & $9 / 181$ & $\mathrm{nt}$ & nt & + & + \\
\hline Listeria & monocytogenes & $3 a$ & + & List-NRC & $8 / 171$ & nt & nt & + & + \\
\hline Listeria & monocytogenes & $3 b$ & + & List-NRC & $8 / 115$ & + & + & + & + \\
\hline Listeria & monocytogenes & $3 b$ & + & List-NRC & Würzburg & + & + & + & + \\
\hline Listeria & monocytogenes & $3 c$ & + & List-NRC & $6 / 64$ & + & + & + & + \\
\hline Listeria & monocytogenes & $3 c$ & + & List-NRC & $6 / 125$ & + & + & + & + \\
\hline Listeria & monocytogenes & $3 c$ & + & List-NRC & $6 / 137$ & nt & $\mathrm{nt}$ & + & + \\
\hline Listeria & monocytogenes & $3 c$ & + & List-NRC & $6 / 275$ & $\mathrm{nt}$ & $\mathrm{nt}$ & + & + \\
\hline Listeria & monocytogenes & $3 c$ & + & List-NRC & $6 / 301$ & nt & nt & + & + \\
\hline Listeria & monocytogenes & $4 \mathrm{a}$ & + & List-NRC & $10 / 118$ & + & + & + & + \\
\hline Listeria & monocytogenes & $4 a$ & + & List-NRC & ATCC 19114 & $\mathrm{nt}$ & $\mathrm{nt}$ & + & + \\
\hline Listeria & monocytogenes & $4 b$ & + & List-NRC & ATCC 51780 & + & + & + & + \\
\hline Listeria & monocytogenes & $4 b$ & + & List-NRC & $10 / 7$ & + & + & + & + \\
\hline Listeria & monocytogenes & $4 b$ & + & List-NRC & $10 / 1$ & nt & $\mathrm{nt}$ & + & + \\
\hline Listeria & monocytogenes & $4 b$ & + & List-NRC & $10 / 3$ & $\mathrm{nt}$ & $\mathrm{nt}$ & + & + \\
\hline Listeria & monocytogenes & $4 b$ & + & List-NRC & $10 / 24$ & nt & nt & + & + \\
\hline Listeria & monocytogenes & $4 b$ & + & List-NRC & $10 / 34$ & nt & $\mathrm{nt}$ & + & + \\
\hline Listeria & monocytogenes & $4 b$ & + & List-NRC & $10 / 47$ & $\mathrm{nt}$ & $\mathrm{nt}$ & + & + \\
\hline Listeria & monocytogenes & $4 c$ & + & EU-RL List & 09LEB41LM & + & + & + & + \\
\hline Listeria & monocytogenes & $4 d$ & + & List-NRC & $8 / 221$ & + & + & + & + \\
\hline Listeria & monocytogenes & $4 d$ & + & List-NRC & $7 / 89$ & nt & $\mathrm{nt}$ & + & + \\
\hline Listeria & monocytogenes & $4 d$ & + & List-NRC & $7 / 114$ & nt & $\mathrm{nt}$ & + & + \\
\hline Listeria & monocytogenes & $4 d$ & + & List-NRC & $5 / 163$ & nt & nt & + & + \\
\hline Listeria & monocytogenes & $4 \mathrm{e}$ & + & List-NRC & $10 / 35$ & + & + & + & + \\
\hline
\end{tabular}


Table 1 (continued)

\begin{tabular}{|c|c|c|c|c|c|c|c|c|c|}
\hline Genus & Species & Serogroup & GRAM & Origin & Reference & $\begin{array}{l}\text { iap- } \\
50-\operatorname{deg}\end{array}$ & $\begin{array}{l}\text { prs- } \\
\text { 2-deg }\end{array}$ & $\begin{array}{l}\text { hlyA- } \\
177\end{array}$ & $\begin{array}{l}\text { hlyA-146- } \\
\text { deg-tronc }\end{array}$ \\
\hline Listeria & ivanovii & & + & List-NRC & CIP 7842 & + & + & - & - \\
\hline Listeria & ivanovii & & + & ILVO & LMG11388 & + & + & - & - \\
\hline Listeria & ivanovii & & + & List-NRC & $06 / 124$ & + & + & - & - \\
\hline Listeria & ivanovii & & + & List-NRC & $06 / 129$ & + & + & - & - \\
\hline Listeria & ivanovii & & + & EU-RL List & TQA237 & + & + & - & - \\
\hline Listeria & ivanovii & & + & EU-RL List & TQA238 & + & + & - & - \\
\hline Listeria & ivanovii & & + & EU-RL List & 00CHPL02 & + & + & - & - \\
\hline Listeria & seeligeri & & + & List-NRC & ATCC 35967 & + & + & - & - \\
\hline Listeria & seeligeri & & + & ILVO & MB43:LMG16764 & + & + & - & - \\
\hline Listeria & seeligeri & & + & EU-RL List & TQA231 & + & + & - & - \\
\hline Listeria & seeligeri & & + & EU-RL List & TQA232 & + & + & - & - \\
\hline Listeria & welshimeri & & + & List-NRC & ATCC 35897 & + & + & - & - \\
\hline Listeria & welshimeri & & + & List-NRC & $06 / 102$ & + & + & - & - \\
\hline Listeria & welshimeri & & + & List-NRC & $06 / 229$ & + & + & $\mathrm{nt}$ & $\mathrm{nt}$ \\
\hline Listeria & welshimeri & & + & List-NRC & $04 / 341$ & + & + & $\mathrm{nt}$ & $\mathrm{nt}$ \\
\hline Listeria & welshimeri & & + & EU-RL List & 02CHPL153 & + & + & $\mathrm{nt}$ & $\mathrm{nt}$ \\
\hline Listeria & welshimeri & & + & EU-RL List & 02CHPL154 & + & + & $\mathrm{nt}$ & $\mathrm{nt}$ \\
\hline Listeria & welshimeri & & + & EU-RL List & 03CHPL91 & + & + & $\mathrm{nt}$ & $\mathrm{nt}$ \\
\hline Listeria & welshimeri & & + & EU-RL List & TQA230 & + & + & nt & nt \\
\hline Listeria & innocua & & + & EU-RL List & 03CHPL98 & + & + & $\mathrm{nt}$ & $\mathrm{nt}$ \\
\hline Listeria & inпосиа & & + & List-NRC & CIP 8011 & + & + & - & - \\
\hline Listeria & innосиа & & + & ILVO & $\begin{array}{l}\text { MB176(T) }= \\
\text { FML2011 }\end{array}$ & + & + & - & - \\
\hline Listeria & innocua & & + & List-NRC & $10 / 85$ & + & + & $\mathrm{nt}$ & $\mathrm{nt}$ \\
\hline Listeria & innocua & & + & List-NRC & $10 / 101$ & + & + & $\mathrm{nt}$ & $\mathrm{nt}$ \\
\hline Listeria & innocua & & + & List-NRC & $10 / 122$ & + & + & $\mathrm{nt}$ & $\mathrm{nt}$ \\
\hline Listeria & innocua & & + & List-NRC & $09 / 158$ & + & + & $\mathrm{nt}$ & $\mathrm{nt}$ \\
\hline Listeria & innосиа & & + & List-NRC & $09 / 221$ & + & + & $\mathrm{nt}$ & $\mathrm{nt}$ \\
\hline Listeria & innocua & & + & List-NRC & $09 / 291$ & + & + & nt & $\mathrm{nt}$ \\
\hline Listeria & innосиа & & + & List-NRC & $08 / 147$ & + & + & $\mathrm{nt}$ & $\mathrm{nt}$ \\
\hline Listeria & innосиа & & + & List-NRC & $07 / 92$ & + & + & $\mathrm{nt}$ & nt \\
\hline Listeria & inпосиа & & + & List-NRC & $06 / 237$ & + & + & $\mathrm{nt}$ & $\mathrm{nt}$ \\
\hline Listeria & innocua & & + & IPH-FP & TIAC 706 & + & + & $\mathrm{nt}$ & $\mathrm{nt}$ \\
\hline Listeria & grayi & & + & List-NRC & ATCC 25401 & - & - & - & - \\
\hline Listeria & grayi & & + & ILVO & LMG16490 & - & - & - & - \\
\hline Aeromonas & hydrophila & & - & IPH-CB & $\begin{array}{c}6688(\mathrm{M} / 2862 \\
(\mathrm{EEQ} 2003 / 2))\end{array}$ & - & - & - & - \\
\hline Bacillus & cereus & & + & IPH-FP & ATCC 14579 & - & - & - & - \\
\hline Bacillus & circulans & & + & IPH-FP & TIAC 100 & - & - & - & - \\
\hline Bacillus & lentus & & + & IPH-FP & TIAC 101 & - & - & - & - \\
\hline Bacillus & lichiniformis & & + & IPH-FP & TIAC 102 & - & - & - & - \\
\hline Bacillus & mycoides & & + & IPH-FP & TIAC 97 & - & - & - & - \\
\hline Bacillus & sphaericus & & + & IPH-FP & TIAC 104 & - & - & - & - \\
\hline Bacillus & subtillis & & + & IPH-FP & TIAC 103 & - & - & - & - \\
\hline Bacillus & thuringiensis & & + & IPH-FP & TIAC 96 & - & - & - & - \\
\hline Brevibacillus & borstelensis & & + & IPH-FP & TIAC 099 & - & - & - & - \\
\hline Brochothrix & thermosphacta & & + & IPH-FP & TIAC 400 & - & - & - & - \\
\hline Campylobacter & coli & & - & IPH-FP & ATCC $33559 \mathrm{~T}$ & - & - & - & - \\
\hline Campylobacter & jejuni & & - & IPH-FP & ATCC 33291 & - & - & - & - \\
\hline Campylobacter & lari & & - & IPH-FP & TIAC 542 & - & - & - & - \\
\hline Carnobacterium & divergens & & + & IPH-FP & Argentijns vlees B21 & - & - & - & - \\
\hline
\end{tabular}


Table 1 (continued)

\begin{tabular}{|c|c|c|c|c|c|c|c|c|c|}
\hline Genus & Species & Serogroup & GRAM & Origin & Reference & $\begin{array}{l}\text { iap- } \\
50-\operatorname{deg}\end{array}$ & $\begin{array}{l}\text { prs- } \\
\text { 2-deg }\end{array}$ & $\begin{array}{l}\text { hlyA- } \\
177\end{array}$ & $\begin{array}{l}\text { hlyA-146- } \\
\text { deg-tronc }\end{array}$ \\
\hline Citrobacter & freundii & & - & IPH-FP & TIAC 554 & - & - & - & - \\
\hline Clostridium & perfingens & & + & IPH-FP & ATCC $13124 \mathrm{~T}$ & - & - & - & - \\
\hline Enterobacter & cloacae & & - & IPH-FP & TIAC 445 & - & - & - & - \\
\hline Enterococcus & faecalis & & + & IPH-CB & ATCC 29212 & - & - & - & - \\
\hline Escherichia & coli & & - & IPH-FP & ATCC 25922 & - & - & - & - \\
\hline Escherichia & coli & $\mathrm{O} 157$ & - & IPH-FP & EH 630 & - & - & - & - \\
\hline Hafnia & alvei & & - & IPH-CB & 7186 & - & - & - & - \\
\hline Klebsiella & pneumoniae & & - & IPH-FP & TIAC 446 & - & - & - & - \\
\hline Lactobacillus & acidophilus & & + & IPH-FP & $\begin{array}{l}\text { Argentijns } \\
\text { vlees A19 }\end{array}$ & - & - & - & - \\
\hline Lactobacillus & brevis & & + & IPH-FP & $\begin{array}{l}\text { Argentijns } \\
\text { vlees A53 }\end{array}$ & - & - & - & - \\
\hline Lactobacillus & curvatus & & + & IPH-FP & $\begin{array}{l}\text { Argentijns } \\
\text { vlees A1 }\end{array}$ & - & - & - & - \\
\hline Lactobacillus & delbrucki & & + & IPH-FP & $\begin{array}{l}\text { Argentijns } \\
\text { vlees B17 }\end{array}$ & - & - & - & - \\
\hline Lactobacillus & plantarum & & + & IPH-FP & $\begin{array}{l}\text { Argentijns } \\
\text { vlees B34 }\end{array}$ & - & - & - & - \\
\hline Lactococcus & lactis lactis & & + & IPH-FP & $\begin{array}{l}\text { Argentijns } \\
\text { vlees A31 }\end{array}$ & - & - & - & - \\
\hline Leuconostoc & citreum & & + & IPH-FP & $\begin{array}{l}\text { Argentijns } \\
\text { vlees B24 }\end{array}$ & - & - & - & - \\
\hline Leuconostoc & mesenteroides & & + & IPH-FP & $\begin{array}{l}\text { Argentijns } \\
\text { vlees B6 }\end{array}$ & - & - & - & - \\
\hline Paenibacillus & polymyxa & & + & IPH-FP & TIAC 105 & - & - & - & - \\
\hline Proteus & vulgaris & & - & IPH-CB & $\begin{array}{l}6223(\mathrm{M} / 654) \\
(\text { EEQ 1996/3) }\end{array}$ & - & - & - & - \\
\hline Pseudomonas & aeruginosa & & - & IPH-FP & LMG 6395 & - & - & - & - \\
\hline Salmonella & enterica enterica & Enteritidis & - & Salm-NRC & $\mathrm{H}, \mathrm{VI}, 6,32$ & - & - & - & - \\
\hline Salmonella & enterica enterica & Thyphimurium & - & Salm-NRC & H, II, 32, 32 & - & - & - & - \\
\hline Serratia & marcescens & & - & IPH-CB & 7015 & - & - & - & - \\
\hline Shigella & sonneï & & - & Salm-NRC & $10-03865$ & - & - & - & - \\
\hline Staphylococcus & aureus & & + & IPH-FP & ATCC 25923 & - & - & - & - \\
\hline Staphylococcus & epidermidis & & + & IPH-FP & TIAC 367 & - & - & - & - \\
\hline Staphylococcus & pisciferm & & + & IPH-FP & TIAC 364 & - & - & - & - \\
\hline Streptococcus & feacales & & + & IPH-FP & TIAC 300 & - & - & - & - \\
\hline Vibrio & parahaemoliticus & & - & IPH-FP & TIAC 610 & - & - & - & - \\
\hline Yersinia & enterocolitica & & - & IPH-FP & LMG 15558 & - & - & - & - \\
\hline Aspergillus & fumigatus & & na & IPH-MA & BCCM/IHEM 19436 & - & - & - & - \\
\hline Cladosporium & sphaerospermum & & na & IPH-MA & BCCM/IHEM 24474 & - & - & - & - \\
\hline Saccharomyces & cerevisiae & & na & IPH-MA & BCCM/IHEM 3961 & - & - & - & - \\
\hline Candida & parapsilosis & & na & IPH-MA & BCCM/IHEM 6478 & - & - & - & - \\
\hline Hepatitis $A$ Virus & & & na & IPH-FP & $27(\mathrm{WZ})$ & - & - & - & - \\
\hline Norovirus & & & na & IPH-FP & 2593 & - & - & - & - \\
\hline \multicolumn{4}{|c|}{ No template control } & na & na & - & - & - & - \\
\hline
\end{tabular}

+ there is an amplification and a $T_{\mathrm{m}}$ value similar for all corresponding strains, - no amplification, List-NRC Belgian Listeria National Reference Centre, rue Juliette Wytsmanstraat 14, 1050 Brussels, Belgium, EU-RL List EU-RL Listeria monocytogenes, 23 avenue du Général de Gaulle, 94706 Maisons-Alfort cedex, France, ILVO Instituut voor Landbouw- en Visserijonderzoek, Technology \& Food Science Unit, Food Safety, Product Quality and Innovation, and Business Unit and Service Centre, Brusselsesteenweg 370, 9090 Melle, Belgium, IPH-FP Scientific Institute of Public Health, Food Pathogens Laboratory, rue Juliette Wytsmanstraat 14, 1050 Brussels, Belgium, IPH-CB Scientific Institute of Public Health, Clinical Biology, rue Juliette Wytsmanstraat 14, 1050 Brussels, Belgium, Salm-NRC Belgian Salmonella and Shigella National Reference Centre, rue Juliette Wytsmanstraat 14, 1050 Brussels, Belgium, IPH-MA Mycology and Aerobiology, Scientific Institute of Public Health, rue Juliette Wytsmanstraat 14, 1050 Brussels, Belgium, $n t$ not tested, na not applicable 
pairs that gave the expected in silico amplification were retained for the in situ test. When mismatches between the primers and one of the targets were observed, degenerate nucleotides were introduced into the primer sequence. However, primer pairs with no degenerate nucleotides were always preferred.

\section{Qualitative SYBR ${ }^{\circledR}$ Green qPCR assay}

All qPCR assays were performed in accordance with the general requirements from the ISO norm 22119 (Anonymous 2011c) except those specific for the TaqMan ${ }^{\circledR}$ chemistry since the SYBR ${ }^{\circledR}$ Green was used. All qPCR assays were performed on an Applied Biosystems 7300 Real-Time PCR System (Applied Biosystems) with MicroAmp ${ }^{\circledR}$ Optical 96-Well Reaction Plate closed with the MicroAmp ${ }^{\circledR}$ Optical 8-Cap Strip (Applied Biosystems). The reaction was performed in a final volume of $25 \mu \mathrm{l}$ containing $5 \mu \mathrm{l}$ of the appropriate template $\left(10^{4}\right.$ copies of gDNA for the selectivity test or serial dilution of gDNA for the sensitivity test), 1X SYBR ${ }^{\circledR}$ Green PCR Mastermix (Diagenode) and the appropriate concentration of each primer (Table 2). The following thermal programme was applied: a single cycle of DNA polymerase activation for $10 \mathrm{~min}$ at $95^{\circ} \mathrm{C}$ followed by 40 amplification cycles of $15 \mathrm{~s}$ at $95{ }^{\circ} \mathrm{C}$ (denaturing step) and $1 \mathrm{~min}$ at $60{ }^{\circ} \mathrm{C}$ (annealing \& extension step). Subsequently, melting temperature analysis of the amplification products was performed by gradually increasing the temperature from 60 to $95^{\circ} \mathrm{C}$ in $20 \mathrm{~min}\left( \pm 0.6{ }^{\circ} \mathrm{C} / 20 \mathrm{~s}\right)$. The fluorescent reporter signal was normalized against the internal reference dye (ROX) signal and the threshold limit setting was performed in automatic mode, according to the ABI Sequence Detection Software version 1.4 (Applied Biosystems). "No template" controls (NTC) using DNase and RNase free water (Acros) were included in each reaction to assess primer dimer formation or non-specific amplification.

For the interpretation of a SYBR ${ }^{\circledR}$ Green qPCR assay, two criteria were taken into consideration: the quantification cycle $\left(C_{\mathrm{q}}\right)$ value and the melting temperature of the amplicon $\left(T_{\mathrm{m}}\right)$. The $C_{\mathrm{q}}$ value represents the fractional cycle at which PCR amplification reaches the threshold level for the reaction (Bustin 2000). Since it is a screening assay, a qualitative response is required. To be considered as positive, a signal generated in SYBR ${ }^{\circledR}$ Green qPCR analysis should display an (exponential) amplification above the threshold level, with a single peak upon melting analysis giving a unique $T_{\mathrm{m}}$ value. A signal was considered as negative when no $C_{\mathrm{q}}$ value was obtained.

Selectivity test and accuracy calculation

Primer pairs that passed the in silico evaluation were tested in situ. The latter selectivity test consisted of two steps:
1. A preliminary selectivity test involving few target strains (closely relative families) and few non-target strains (most important pathogenic bacteria) was performed. Primer pairs amplifying only the target strains were tested for full selectivity.

2. The full selectivity test allows testing the inclusivity and exclusivity of each developed assay. This experimental design follows the ISO 22118 norm (Anonymous 2011b) as it involves 50 target strains and at least 52 non-target strains representing 53 species belonging to 29 genera and a NTC (Table 1) (Anonymous 2011b). The non-target relevant microorganisms to test the exclusivity were chosen among taxonomically closely related and not closely related (pathogenic or not) bacteria that can be present in the food matrices (Anonymous 2011b).

The qPCR reactions were performed with approximately $10^{4}$ copies of genomic DNA calculated according to the genome size of each targeted bacteria using the following formula:

$$
\begin{gathered}
m \times \mathrm{Ac} \\
C_{\mathrm{n}}=-------- \\
M_{\mathrm{w}} \times G_{\mathrm{s}}
\end{gathered}
$$

where $C_{\mathrm{n}}=$ copy number, $m=$ amount of gDNA (grams), $\mathrm{Ac}=$ Avogadro's constant (Mohr et al. 2008) $=6.02214179 \times 10^{23}$ $\mathrm{mol}^{-1}, M_{\mathrm{w}}=$ base pair mean molecular weight $=649 \mathrm{Da}$ and $G_{\mathrm{s}}=$ Genome size (in base pairs).

The accuracy of the assay can be calculated from the selectivity test. The accuracy represents the closeness of agreement between a test result and the accepted reference value (Anonymous 1993). Its formula is found in Anonymous (2003). Five criteria were set to define a "specific signal" generated in the selectivity of a SYBR ${ }^{\circledR}$ Green qPCR analysis (Barbau-Piednoir et al. 2010): (1) an (exponential) amplification above the threshold level should be obtained with template DNA for the positive strains, while negative controls (NTC and gDNA from negative strains) should not yield such amplification, (2) with positive strain template DNA, the obtained PCR product(s) should present a single peak upon melting analysis with a unique $T_{\mathrm{m}}$ value, while no specific peak should be detectable in the negative strains and negative controls, (3) positive reactions should display a single band on agarose gel analysis with (4) a size corresponding to the one predicted ( $\mathrm{SD} \pm 10 \mathrm{bp}$ ) and (5) the sequence of the amplicon, verified by sequencing, should be correct as to guarantee that the amplified fragment is indeed the target.

Amplicon cloning and sequencing

All PCR reactions for cloning and sequencing were performed on an iCycler PCR System (Biorad) in 25- $\mu$ l 
reaction volume containing $10^{6}$ copies of gDNA, $1 \mathrm{U}$ Pfu DNA Polymerase (Fermentas), 1X DNA polymerase buffer, $0.2 \mathrm{mM}$ of each dNTP and $250 \mathrm{nM}$ of each primer (Table 2; $\mathrm{T} 7$ forward and M13 reverse primer). The following thermal programme was applied: a single cycle of initial denaturation for $2 \mathrm{~min}$ at $95^{\circ} \mathrm{C}$ followed by 30 amplification cycles of $15 \mathrm{~s}$ at $95{ }^{\circ} \mathrm{C}$ (denaturing step), $15 \mathrm{~s}$ at $60^{\circ} \mathrm{C}$ (annealing step) and $1 \mathrm{~min}$ at $72^{\circ} \mathrm{C}$ (extension step). A subsequent final elongation step of the amplification products was performed using $72{ }^{\circ} \mathrm{C}$ for $10 \mathrm{~min}$.

PCR fragments obtained by "classical" PCR amplification using L. monocytogenes $1 / 2 \mathrm{a}$ strain ATCC 51772 as template were cloned into a TOPO $\mathrm{pCR}^{\circledR}{ }^{\circledR} 2.1$ plasmid (InVitrogen) according to the manufacturer's recommendations. The plasmids containing the different amplicons (TOPO $\mathrm{pCR}^{\circledR}$ 2.1-amplicon) were transformed into TOP10F' competent cells (InVitrogen) according to the manufacturer's recommendations. The "TOPO pCR 2.1-amplicon" was checked for insert length by PCR reaction using T7 forward and M13 reverse primers. Agarose gel electrophoresis was performed using 1 or $3 \%$ precast gels (Biorad) and $1 \mathrm{x}$ TBE ( $89 \mathrm{mM}$ TRIS-borate, $2 \mathrm{mM}$ EDTA) at $100 \mathrm{~V}$ for $15 \mathrm{~min}$, including a 100-bp-2-kb Molecular Marker (BioRad). Plasmids that gave the expected size on agarose gel were purified with the Plasmid Mini kit (Qiagen). The inserts were then sequenced with the T7 forward and M13 reverse primers using a dideoxy sequence analysis on an ABI3130xl Genetic Analyzer apparatus (Applied Biosystems) with the BigDye Terminator v3.1 cycle sequencing kit (Applied Biosystems) according to the manufacturer's recommendations. Forward and reverse sequences of a "TOPO pCR2.1-amplicon" plasmid were aligned by ClustalW2 software (http:// www.ebi.ac.uk/Tools/msa/clustalw2/). The amplicon sequence was compared to NCBI sequences database (MEGABLAST) to confirm that it corresponds to the target gene (http://blast.ncbi.nlm.nih.gov/Blast.cgi).

\section{Determination of the optimal primer concentration}

The optimal concentration of the selected primer pairs was determined by testing different concentrations of each primer between 250 and $1,000 \mathrm{nM}$. The concentrations giving the lowest $C_{\mathrm{q}}$ value without inducing the formation of a high level of primer dimers were selected. The primer dimer dissociation peak should not be higher than the dissociation peak from the positive samples from high concentrations until the limit of detection (LOD).

\section{Dynamic range and calculation of the PCR efficiency}

The dynamic range of an assay is the concentration range where it performs in a linear manner. The SYBR ${ }^{\circledR}$ Green qPCR assays' dynamic range was assessed by the analysis in

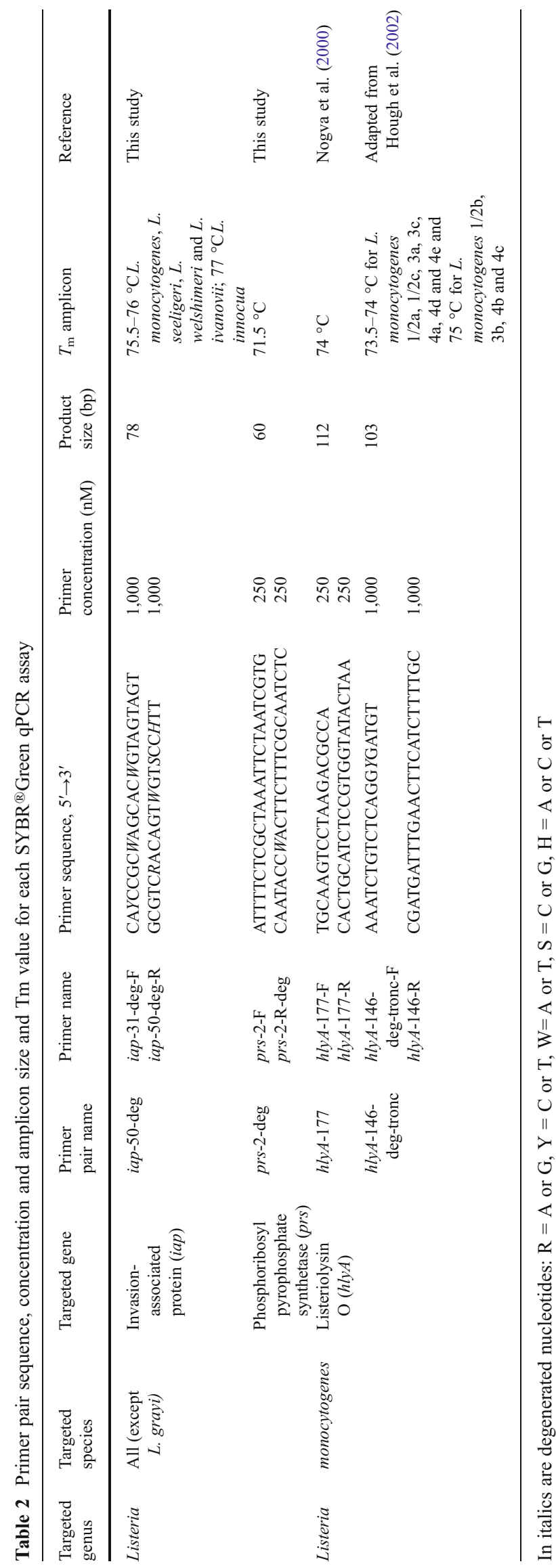


duplicate of a serial dilution in a carrier DNA (4 ng/ $\mu$ l calf thymus DNA (Invitrogen)) of pure strain DNA $(1,000$ to 0.01 theoretical genomic copies) of $L$. monocytogenes $1 / 2 \mathrm{a}$ ATCC 51772 and L. ivanovii LMG 11388 for Listeria spp. assays and $L$. monocytogenes $1 / 2$ a ATCC 51772 and $L$. monocytogenes 4b ATCC 51777 for L. monocytogenes assays. The carrier DNA is meant to avoid the dilution problem associated with low gDNA concentration. These analyses allow the assessment of the coefficient of determination $\left(R^{2}\right)$ and the PCR efficiency $(E)$ for each $\mathrm{SYBR}^{\circledR}$ Green qPCR assay. $R^{2}$ is an indicator of the correlation of data regarding the linear regression curve. $R^{2}$ of a dynamic range curve should be above 0.98 (Anonymous 2008a). $E$ should be between 89.6 and $110.2 \%$ (Anonymous 2008a) and can be calculated according to the formula described in Rutledge and Cote (2003).

\section{Sensitivity test}

Primer pairs passing the selectivity test were subsequently examined for their sensitivity. Using serial dilution, the SYBR ${ }^{\circledR}$ Green qPCR assays were tested to evaluate their LOD, which is defined as the concentration of an analyte that gives a positive result with a probability of $95 \%$ (Anonymous 2008). The strains used were L. monocytogenes $1 / 2$ a ATCC 51772 and L. ivanovii LMG 11388 for Listeria spp. assays and L. monocytogenes 1/2a ATCC 51772 and L. monocytogenes $4 \mathrm{~b}$ ATCC 51777 for L. monocytogenes assays. The calculation of the target genomic copy numbers for each dilution point was done according to the equation given in the selectivity part, considering that the gDNA size of $L$. monocytogenes and L. ivanovii are 2,976,163 bp (accession \# CP002816) and 2,928,879 bp (accession \# FR687253), respectively. To determine LOD, a range of copy number between 10 and 0.1 theoretical copies was tested (i.e. 10, 5, 2, 1, 0.5, 0.2 and 0.1 ). Each dilution was tested in six replicates per plate for both strains. Moreover, the analysis was performed three independent times under repeatable conditions, resulting in 36 repeats for each dilution point. The dilution series continued after the theoretical single copy to assess the dilution series correctness. Indeed it is statistically impossible to get amplification in all the reactions with the dilutions below 1 theoretical copy. If this is the case, the template concentration has to be checked and the dilution series have to be redone.

\section{Repeatability calculation}

To evaluate the repeatability of the assays, the data from the independent tests performed for the sensitivity test, with the same protocol, with the same samples and by the same operator using the same apparatus within a short interval of time (Anonymous, 1993) were used. The repeatability limit $(r)$ is the maximal difference between two test results, obtained under repeatable conditions, expected with a probability of $95 \%$ (Anonymous, 1993). In future analyses, if the difference between values obtained under repeatable conditions exceeds $r$, the values should be considered suspicious. The repeatability limit is obtained with the formula found in Anonymous (2003).

The relative standard deviation of repeatability (RSDr) represents the absolute value of the coefficient of variation. It is expressed in percent and is obtained by multiplying the repeatability standard deviation by 100 and dividing this product by the repeatability median (Anonymous 2003).

According to the guidelines of Anonymous (2008a), RSDr should be $\leq 25 \%$ for all the dilutions above LOD. The RSDr and $r$ values of the $C_{\mathrm{q}}$ values have been calculated at each dilution point. The RSDr and $r$ values of the $T_{\mathrm{m}}$ values have been calculated with all the $T_{\mathrm{m}}$ values coupled with amplification $\left(C_{\mathrm{q}} \neq 40\right)$.

Reproducibility study and calculation

To evaluate the reproducibility of the assays (Anonymous 1993), independent tests were performed with the same protocol, using the same eight samples, in two different laboratories by two different operators using two different apparatus (ABI7300 and Bio-Rad iQ5). The eight samples tested were all gDNA from $L$. monocytogenes strains at different concentrations between 200 and 5 genomic copies per reaction. Each sample was analysed in duplicate by each operator.

Two reproducibility measures can be calculated from these results: the relative standard deviation of reproducibility $\left(\mathrm{RSD}_{\mathrm{R}}\right)$ and the uncertainty $(U) \cdot \mathrm{RSD}_{\mathrm{R}}$ represents the absolute value of the coefficient of variation. It is expressed in percent and is obtained by multiplying the reproducibility standard deviation by 100 and dividing this product by the reproducibility median (Anonymous 2003).

According to the guidelines of ENGL (Anonymous 2008a), $R_{S D}$ should be $\leq 35 \%$ for all samples tested. The $\mathrm{RSD}_{\mathrm{R}}$ of the $C_{\mathrm{q}}$ and TM values are calculated for the eight samples tested.

"The uncertainty is the parameter associated with the result of a measurement that characterizes the dispersion of the values that could reasonably be attributed to the measurand" (Anonymous 2008b). The uncertainty of the $C_{\mathrm{q}}$ and $T_{\mathrm{m}}$ values of each SYBR ${ }^{\circledR}$ Green qPCR assay could be calculated from the results of the reproducibility test. The uncertainty can be expressed by the expanded uncertainty $(U)$ which is the quantity defining "an interval about the result of a measurement that may be expected to encompass a large fraction of the distribution of values that could reasonably be attributed to the measurand" (Anonymous 2008b).

The expanded uncertainty $U$ is obtained by multiplying the combined standard uncertainty by a coverage factor (Anonymous 2008b). 
Combination of the four SYBR ${ }^{\circledR}$ Green qPCR detection assays

The four assays have been run, on the same plate with the same PCR programme (as described previously), using the appropriate concentration of each primer (Table 2) on $10^{4}$ copies of four gDNA extractions from pure culture of $L$. monocytogenes 4b (ATCC 51780), L. ivanovii (CIP 7848), L. seeligeri (ATCC 25401) and L. grayi (ATCC 25401). All of these strains were collected from the Belgian National Reference Centre of L. monocytogenes.

\section{Results}

Development and selection of qPCR SYBR ${ }^{\circledR}$ Green assays

\section{Selection of the targeted genes}

First, a survey of available genetic and genomic data was performed in order to select the Listeria genus and L. monocytogenes species-specific genes. For the Listeria genus, three genes were retained: iap, belonging to the known virulence genes of Listeria (Kuhn and Goebel 1989), and $l d h$ and prs that are not involved in the virulence but directly flank a virulence gene cluster (Schmid et al. 2005). These three genes are present in all Listeria species (Schmid et al. 2005). For the specific detection of L. monocytogenes, the chosen gene was $h l y A$. This gene is involved, and is crucial, in the virulence of L. monocytogenes (Dussurget et al. 2004). The four selected genes (iap, prs, $l d h$ and $h l y A$ ) are present in a single copy on Listeria chromosomes (Dussurget et al. 2004; Schmid et al. 2005).

\section{Selection of the primer pairs}

For the detection of the Listeria genus, 50 primer pairs were designed on iap, prs and $l d h$ genes and tested together with another previously described iap-based primer pair (Klein and Juneja 1997). For the detection of L. monocytogenes, three $h l y A$-based primer pairs were selected from previous works (Hough et al. 2002; Nogva et al. 2000; Thulin Hedberg et al. 2009). After in silico evaluation of all these primer pairs and degeneration of some nucleotides (when necessary), 19 a

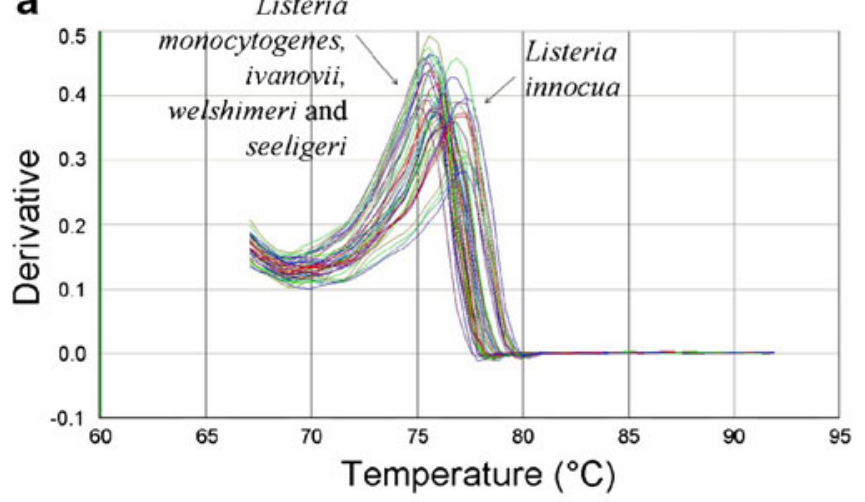

b

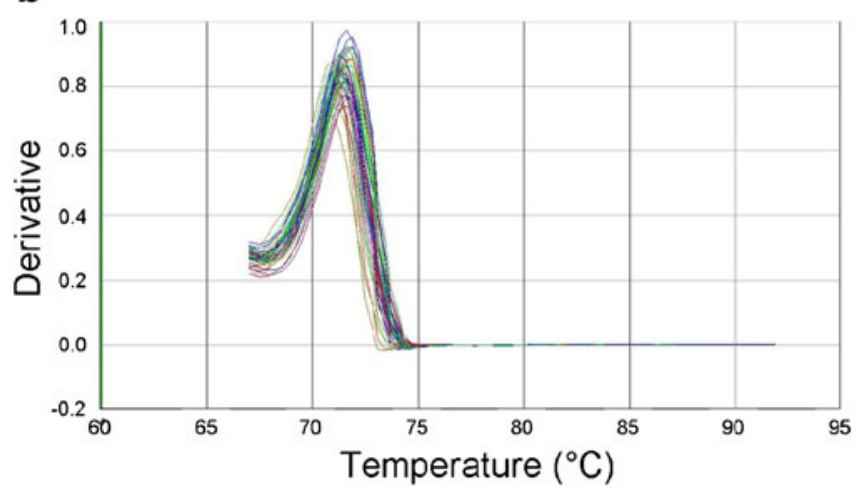

Fig. 1 Melting curves obtained by SYBR ${ }^{\circledR}$ Green qPCR analysis of the positive pure strains listed in Table 1 . The different qPCR assays are iap-50-deg (a), prs-2-deg (b), hlyA-177 (c) and hlyA-146-deg-tronc

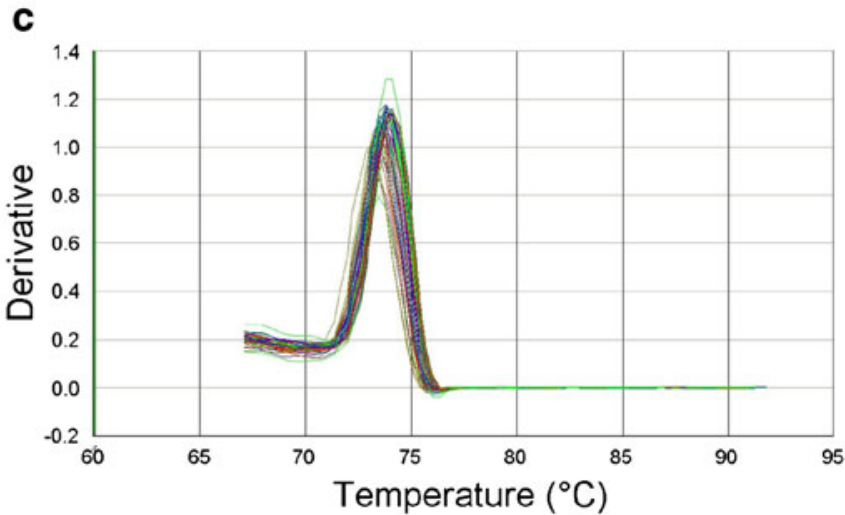

d

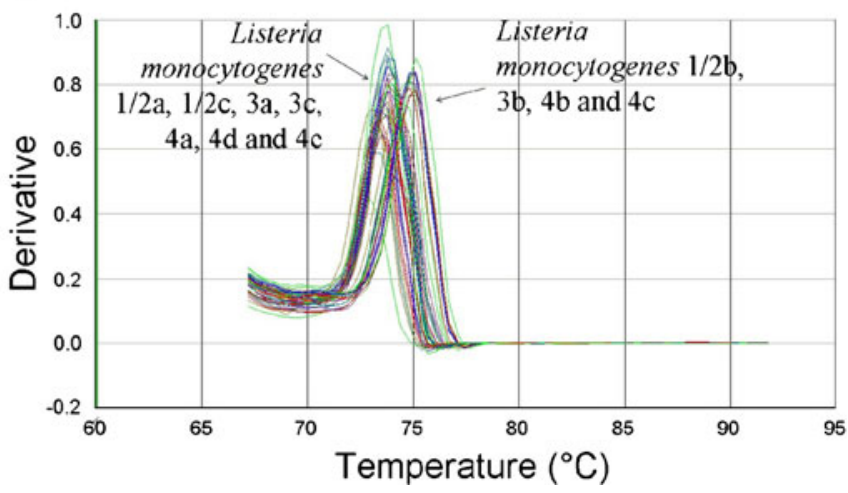

(d). The temperature is plotted on the $X$-axis versus the inverse of the first derivate of the best-fitted curve of the measured fluorescence decrease on the $Y$-axis 
primer pairs remained. These 19 primer pairs were tested in situ with the preliminary selectivity test (data not shown) and resulted in only six pairs: iap-55-deg, iap-50-deg, ldh-2 and prs-2-deg for the Listeria spp. detection and hlyA-177 and hlyA146-deg-tronc for the L. monocytogenes detection. These six pairs were then tested to determine the optimal concentration to be used in the SYBR ${ }^{\circledR}$ Green qPCR amplification (see Table 2). Following this test, the iap-55-deg pair was discarded because of the formation of a high level of primer dimers.

\section{Determination of SYBR ${ }^{\circledR}$ Green qPCR assays selectivity}

Table 1 gives an overview of the strains tested for the selectivity test of each qPCR assay. For iap-50-deg and prs-2-deg Listeria spp. detection assays, a specific amplification was observed for 50 of the 52 target strains. The two L. grayi strains showed no amplification. As expected, no amplification was observed with the 52 non-target strains and the NTC (Table 1). Thus, these first two assays are $98.08 \%$ accurate for their target (Listeria spp.), giving $0 \%$ of false positive and $3.85 \%$ of false negative (two strains of $L$. grayi) results. The $l d h-2$ primer pair assay was discarded during the sensitivity study because of a high level of primer dimers at low target concentrations (data not shown). It has to be mentioned that $L$. marthii (accession \# NZ_CM001047.1), which is close to $L$.

a

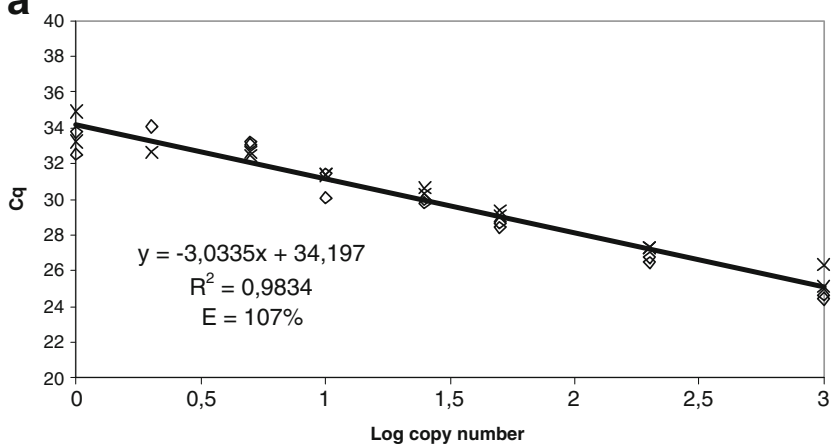

b

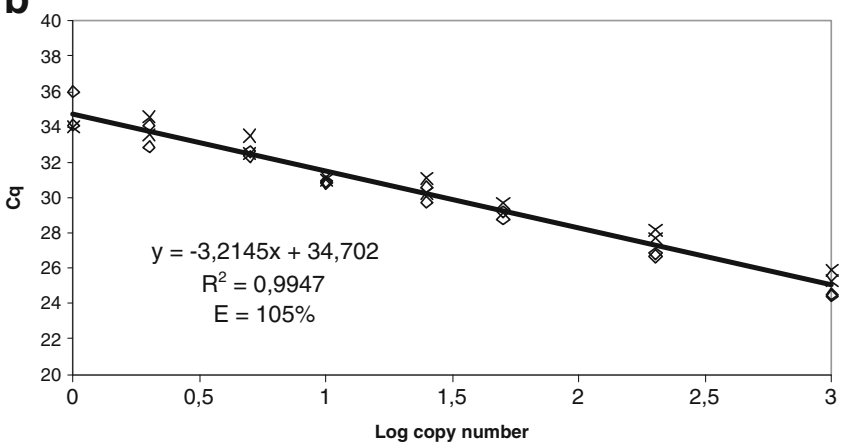

Fig. 2 Dynamic range, coefficient of determination and PCR efficiency of the four Listeria SYBR ${ }^{\circledR}$ Green qPCR assays methods. Curves were obtained from two replicates for each concentration (expressed in copy number) from two different strains. a iap-50-deg, b prs-2-deg, c innocua and L. monocytogenes (Graves et al. 2010) can be amplified, in silico, by the Listeria spp. assays (data not shown) and not by the L. monocytogenes assays (data not shown). L. rocourtiae, which is closely related to $L$. grayi (Leclercq et al. 2010), will probably be amplified by none of the developed SYBR ${ }^{\circledR}$ Green qPCR assays.

For hlyA-177 (Nogva et al. 2000) and hlyA-146-deg-tronc (adapted from Hough et al. 2002) L. monocytogenes detection strategy, a specific amplification was observed with the 50 target strains and no amplification was observed with the 65 non-target strains and the NTC (Table 1). These two approaches are $100 \%$ accurate for their targets (L. monocytogenes), giving $0 \%$ of false positive and $0 \%$ of false negative results.

These four assays always gave rise to a unique band of the expected size and the sequence of each amplicon corresponded with the one expected of L. monocytogenes (data not shown). In addition, all four SYBR ${ }^{\circledR}$ Green qPCR assays gave a unique melting peak for each target with different $T_{\mathrm{m}}$ values (see Fig. 1 and Table 2).

Determination of dynamic range and PCR efficiency of SYBR ${ }^{\circledR}$ Green qPCR assays

All of the assays performed in a linear manner between 1,000 and 1 copy of the targeted gene since the $R^{2}$ values

C

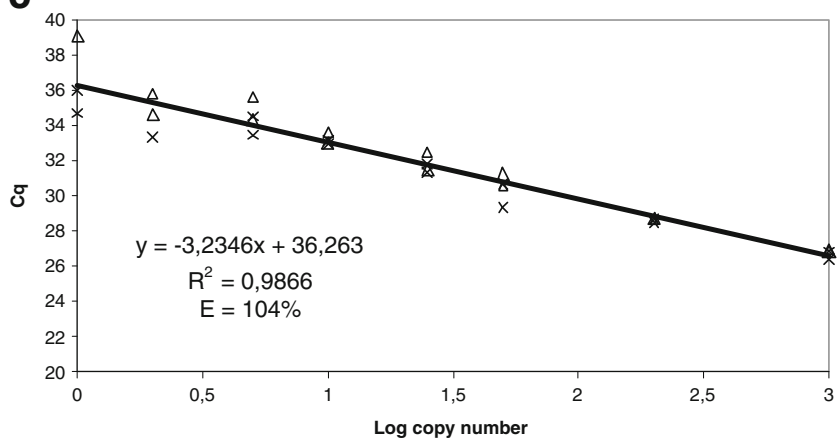

d

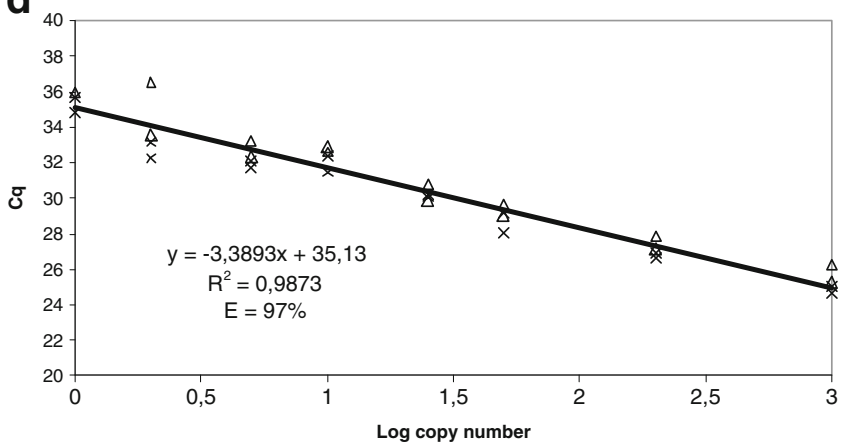

hlyA-177, d hlyA-146-deg-tronc. Multiplication symbol L. monocytogenes 1/2a (ATCC 51772), open diamond L. ivanovii (LMG 11388), open triangle L. monocytogenes $4 \mathrm{~b}$ (ATCC 51777) 
of the four assays, iap-50-deg, prs-2-deg, hlyA-177 and hlyA-146-deg-tronc, ranged between 0.9834 and 0.9947 (Fig. 2). The results from the dynamic range analyses allowed the determination of the PCR efficiency $(E)$ of each of the four developed SYBR ${ }^{\circledR}$ Green qPCR assays. The four assays displayed a PCR efficiency of 107, 105, 104 and $97 \%$ for iap-50-deg, prs-2-deg, hlyA-177 and hlyA-146deg-tronc, respectively (Fig. 2). The $R^{2}$ and $E$ values of the developed SYBR ${ }^{\circledR}$ Green qPCR comply with the acceptance limits.

Determination of sensitivity and repeatability of SYBR ${ }^{\circledR}$ Green qPCR assays

LOD was identified to be between two to five copies for the four SYBR ${ }^{\circledR}$ Green qPCR assays: iap-50-deg, prs-2-deg, $h l y A-177$ and hlyA-146-deg-tronc (Table 3). The $r$ value at LOD of the $C_{\mathrm{q}}$ values ranges between 1.5 to $4.8 C_{\mathrm{q}}$ (Table 4 ). The $r$ value of the $T_{\mathrm{m}}$ values ranges between 0.5 to $1.3{ }^{\circ} \mathrm{C}$ (Table 5). The RSDr value at LOD of the $C_{\mathrm{q}}$ values was below $5 \%$ for the four developed assays ranging between 1.6 and $4.9 \%$. The RSDr value of the $T_{\mathrm{m}}$ values was below $1 \%$ for the four developed assays ranging between 0.2 and $0.6 \%$ (Table 5). The LOD and $\mathrm{RSD}_{\mathrm{r}}$ values of the developed SYBR ${ }^{\circledR}$ Green qPCR comply with the acceptance limits.

\section{Determination of reproducibility of SYBR ${ }^{\circledR}$ Green qPCR assays}

The $\mathrm{RSD}_{\mathrm{R}}$ was calculated for each sample on the $C_{\mathrm{q}}$ and the $T_{\mathrm{m}}$ values (Table 6). For each SYBR ${ }^{\circledR}$ Green qPCR assay, this $\mathrm{RSD}_{\mathrm{R}}$ was between 0.05 and $0.95 \%$ for the $T_{\mathrm{m}}$ values and was between 0.23 and $6.19 \%$ for the $C_{\mathrm{q}}$ values. The $\mathrm{RSD}_{\mathrm{R}}$ values of the developed SYBR ${ }^{\circledR}$ Green qPCR comply with the acceptance limits. The expanded uncertainty at $99 \%$ of confidence has also been calculated from the reproducibility data from the eight samples. $U$ was ranging between 0.46 and $1.42{ }^{\circ} \mathrm{C}$ for the $T_{\mathrm{m}}$ values and between 0.95 and $3.72 C_{\mathrm{q}}$ for the $C_{\mathrm{q}}$ values (Table 6).

Combination of the four SYBR ${ }^{\circledR}$ Green qPCR detection assays

Since the CoSYPS Path Food system is a screening (qualitative) system, the detection and discrimination of several Listeria species have been examined. The four assays have been run, on the same plate with the same PCR programme (as described previously), using the appropriate concentration of each primer (Table 2) on four gDNA extractions from pure cultures of $L$. monocytogenes serotype $4 \mathrm{~b}$, L. ivanovii, L. seeligeri and $L$. grayi. The four SYBR ${ }^{\circledR}$ Green qPCR assays amplified $L$. monocytogenes with a $C_{\mathrm{q}}$

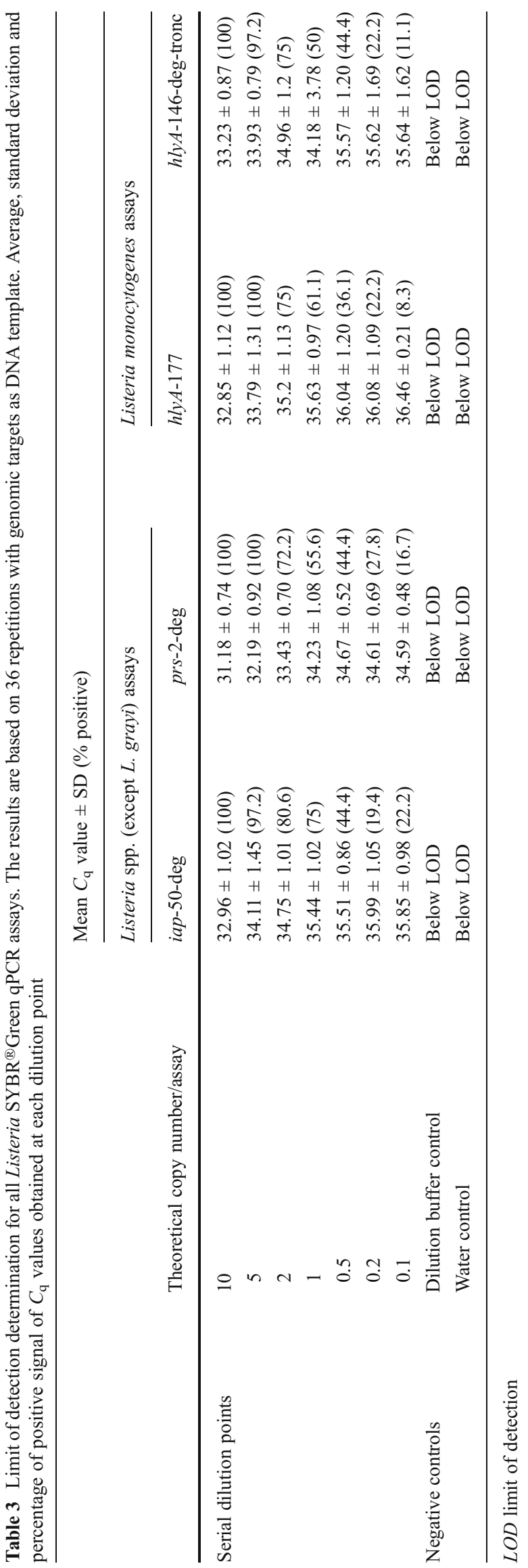


Table 4 Repeatability of the $\mathrm{Cq}$ values at the LOD for all Listeria SYBR ${ }^{\circledR}$ Green $\mathrm{qPCR}$ assays. The results are based on 36 repetitions with genomic targets as DNA template

na not applicable, $L O D$ limit of detection

\begin{tabular}{|c|c|c|c|c|c|c|}
\hline & \multicolumn{6}{|c|}{ Repeatability calculation on $C_{\mathrm{q}}$ values at the LOD } \\
\hline & \multicolumn{2}{|c|}{$\begin{array}{l}\text { L. monocytogenes } 1 / 2 \mathrm{a} \\
\text { (ATCC } 51772 \text { ) }\end{array}$} & \multicolumn{2}{|c|}{$\begin{array}{l}\text { L. monocytogenes } \\
\text { 4b (ATCC 51777) }\end{array}$} & \multicolumn{2}{|c|}{$\begin{array}{l}\text { Listeria ivanovii } \\
\text { (LMG 11388) }\end{array}$} \\
\hline & RSDr (\%) & $r$ & RSDr (\%) & $r$ & RSDr (\%) & $r$ \\
\hline iap-50-deg & 4.9 & 4.8 & na & na & 2 & 1.9 \\
\hline prs-2-deg & 2.4 & 2.2 & na & na & 2.3 & 2.1 \\
\hline hlyA-177 & 3.8 & 3.6 & 4.1 & 3.8 & na & na \\
\hline hlyA-146-deg-tronc & 1.6 & 1.5 & 2.9 & 2.8 & na & na \\
\hline
\end{tabular}

value which is comparable between assays (Tables 7 and 8). The species L. ivanovii and L. seeligeri were amplified by the two assays amplifying the Listeria spp. The species L. grayi was amplified by none of the four assays (Tables 7 and 8).

\section{Discussion}

L. monocytogenes is an important foodborne pathogen and is widely tested in food, environmental and clinical samples (Gasanov et al. 2005). The detection of L. monocytogenes is traditionally performed with culture methods using selective enrichment and plating, followed by characterization based on colony morphology and biochemical properties (Anonymous 1996a). Such methods are labour intensive and time consuming. Therefore, in the last decade, the need arose for the development of rapid detection methods (Postollec et al. 2011), especially in the case of bio-emergency. The development of PCR or qPCR assays in the field of microbiology has increased markedly and they are now generally accepted as a faster alternative to the conventional microbiological methods (Postollec et al. 2011). However, the success of a PCR or qPCR assays is based on the primer pair design and its efficient evaluation.

In this study, four qualitative SYBR ${ }^{\circledR}$ Green qPCR assays have been successfully developed to detect the presence of
Listeria genus bacteria, as well as the specific identification of L. monocytogenes. The four SYBR ${ }^{\circledR}$ Green qPCR assays targets the iap and $h l y A$ virulence genes and prs, a gene flanking a virulence cluster. The SYBR ${ }^{\circledR}$ Green qPCR strategy described is based on two detection levels. A first set of generic assays allows the detection of the presence of all bacteria belonging to the Listeria genus (except L. grayi). A second set of assays allows the specific detection of $L$. monocytogenes.

L. grayi is not detected by the first set of assays because L. grayi is a species that genetically differs significantly from the other species of the Listeria genus (e.g. $56 \%$ amino acid homology for iap gene between L. monocytogenes and L. grayi) (Schmid et al. 2005). This was confirmed by the multiple alignment of the amplicons of iap50-deg and prs-2-deg assays (data not shown). It is also important to note that the newly characterized species of $L$. marthii and $L$. rocourtiae strains have not been tested in situ since they were not available at the time of the experiments.

These qualitative SYBR ${ }^{\circledR}$ Green qPCR assays to detect Listeria spp. and discriminate L. monocytogenes were developed to be run simultaneously using a uniform PCR programme. Furthermore, in order to avoid any false negative detection due to sequence variation between strains, two SYBR ${ }^{\circledR}$ Green qPCR assays have been developed for each level of specificity: Listeria genus and L. monocytogenes.

Table 5 Repeatability of the Tm values for all Listeria $\mathrm{SYBR}^{\circledR}$ Green $\mathrm{qPCR}$ assays. The results are based on all Tm values coupled with amplification $(\mathrm{Cq} \neq 40)$

Repeatability calculation on $T_{\mathrm{m}}$ value

\begin{tabular}{|c|c|c|c|c|c|c|c|c|}
\hline \multicolumn{3}{|c|}{ L. monocytogenes $1 / 2$ a (ATCC 51772 ) } & \multicolumn{3}{|c|}{ L. monocytogenes 4b (ATCC 51777) } & \multicolumn{3}{|c|}{ Listeria ivanovii (LMG 11388) } \\
\hline $\begin{array}{l}T_{\mathrm{m}} \text { value } \pm \mathrm{SD} \\
\left({ }^{\circ} \mathrm{C}\right)\end{array}$ & $\begin{array}{l}\text { RSDr } \\
(\%)\end{array}$ & $r$ & $\begin{array}{l}T_{\mathrm{m}} \text { value } \pm \mathrm{SD} \\
\left({ }^{\circ} \mathrm{C}\right)\end{array}$ & RSDr (\%) & $r$ & $\begin{array}{l}T_{\mathrm{m}} \text { value } \pm \mathrm{SD} \\
\left({ }^{\circ} \mathrm{C}\right)\end{array}$ & $\begin{array}{l}\text { RSDr } \\
(\%)\end{array}$ & $r$ \\
\hline $76.8 \pm 0.4$ & 0.6 & 1.2 & $\mathrm{nt}$ & na & na & $75.9 \pm 0.5$ & 0.6 & 1.3 \\
\hline $71.3 \pm 0.2$ & 0.2 & 0.5 & $\mathrm{nt}$ & na & na & $71.1 \pm 0.3$ & 0.4 & 0.7 \\
\hline $74.3 \pm 0.2$ & 0.3 & 0.6 & $73.7 \pm 0.3$ & 0.4 & 0.9 & $\mathrm{nt}$ & na & na \\
\hline $74 \pm 0.4$ & 0.6 & 1.2 & $74.5 \pm 0.3$ & 0.4 & 0.9 & nt & na & na \\
\hline
\end{tabular}

$n t$ not tested, na not applicable 


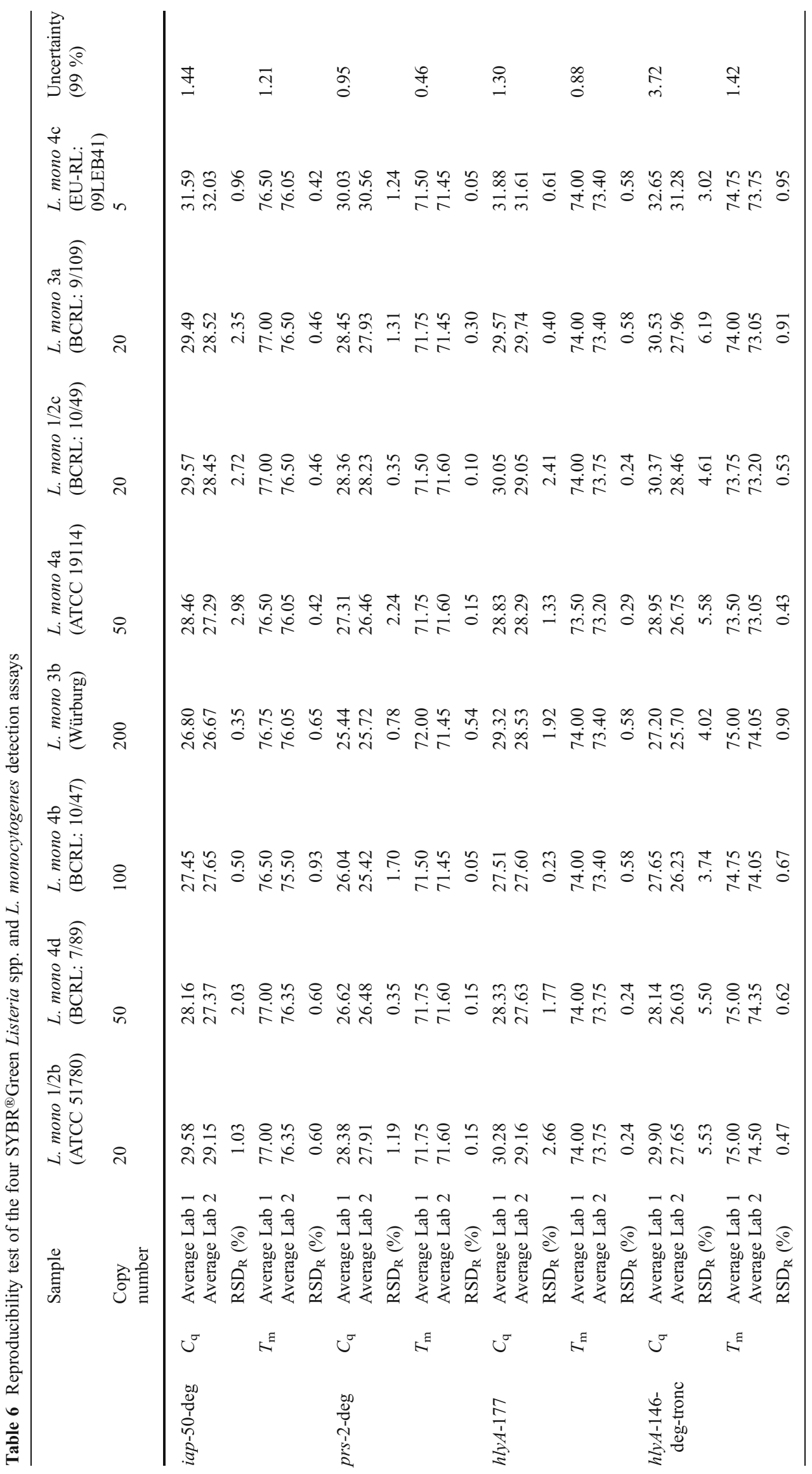


Table 7 Matrix of targets amplification with the four SYBR ${ }^{\circledR}$ Green qPCR assays

\begin{tabular}{llcccc}
\hline Genus & Species & iap-50-deg & prs-2-deg & hlyA-177 & hlyA-146-deg-tronc \\
\hline Listeria & monocytogenes & + & + & + & + \\
Listeria & ivanovii & + & + & - & - \\
Listeria & seeligeri & + & + & - & - \\
Listeria & welshimeri & + & + & - & - \\
Listeria & innocua & + & + & - & - \\
Listeria & grayi & - & - & - & - \\
\hline
\end{tabular}

The SYBR ${ }^{\circledR}$ Green chemistry has been chosen for these qualitative detection assays since it is important to detect all strains. Indeed, with the TaqMan ${ }^{\circledR}$ technology, two primers and one probe should be designed instead of only two primers for the SYBR ${ }^{\circledR}$ Green technology. A higher homology of the amplicon sequence would then be required with TaqMan ${ }^{\circledR}$ technology. For instance, in the 37 nt length between the two primers of iap-50-deg assay, at least seven mismatches were observed among the different Listeria species (data not shown). Moreover, the $\mathrm{SYBR}^{\circledR}$ Green chemistry is less expensive than TaqMan ${ }^{\circledR}$ and allows a post-amplification verification of specificity of the amplicon (Postollec et al. 2011). All of these advantages make SYBR ${ }^{\circledR}$ Green technology the best choice for a screening system.

Most published PCR and qPCR assays to detect foodborne pathogens are not homogeneously validated (O'Grady et al. 2008; Oravcova et al. 2006; Rossmanith et al. 2006). ISO 22119 (Anonymous 2011c) gives the general definitions and requirements about the use of qPCR in food microbiology but does not give performance criteria and their acceptance limits to validate a qPCR assay. To date, the evaluation of the application of qPCR assay in food microbiology is performed according to ISO 16140 (Anonymous 2003), e.g. Rossmanith et al. (2006). This ISO 16140 norm gives the guidelines and acceptance criteria to compare an alternative method with the ISO reference method but does not allow the validation of the developed qPCR assays itself. In the present study, we propose a guideline to validate $\mathrm{qPCR}$ assays applied to food microbiology. All of the developed assays were evaluated for a set of performance criteria, specific to the qPCR applied to food microbiology. These performance criteria are not listed in an available guideline, so they were extracted from two available guidelines (Anonymous 2011b, 2008a). The first guideline is giving performance criteria to evaluate a PCR assay in food-microbiology (Anonymous 2011b), while the second (Anonymous 2008a) gives a list of performance criteria and their acceptance limits specific to the qPCR to evaluate a qPCR assay applied to genetically modified organisms (GMO) detection. Indeed, in the GMO field, qPCR is

Table 8 Matrix of targets amplification with the four SYBR ${ }^{\circledR}$ Green qPCR assays: experimental verification

\begin{tabular}{|c|c|c|c|c|c|c|c|c|c|}
\hline \multirow{2}{*}{$\frac{\text { Sample Name }}{\text { L. monocytogenes } 4 \mathrm{~b}}$} & \multirow{2}{*}{$\begin{array}{l}\text { Detector } \\
C_{\mathrm{q}}\end{array}$} & \multicolumn{2}{|c|}{ iap-50-deg } & \multicolumn{2}{|c|}{ prs-2-deg } & \multicolumn{2}{|c|}{ hlyA-177 } & \multicolumn{2}{|c|}{ hlyA-146-deg-tronc } \\
\hline & & 23.45 & 22.99 & 21.66 & 21.57 & 22.95 & 22.75 & 22.48 & 22.58 \\
\hline & $T_{\mathrm{m}}$ & 76.9 & 76.9 & 71.7 & 71.7 & 74.1 & 74.1 & 74.7 & 74.7 \\
\hline & $\begin{array}{l}\text { Conclusion } \\
\text { Average } C_{\mathrm{q}} \\
\text { St dev } C_{\mathrm{q}}\end{array}$ & $\begin{array}{l}\text { Listeric } \\
22.55 \\
0.65\end{array}$ & p. present & Listeri & p. present & L. mon & enes present & L. mon & enes present \\
\hline \multirow[t]{4}{*}{ L. ivanovii } & $C_{\mathrm{q}}$ & 23.69 & 23.29 & 22.23 & 22.11 & Und & Und & 34.67 & 38.67 \\
\hline & $T_{\mathrm{m}}$ & 75.9 & 76.3 & 71.7 & 71.7 & 72.6 & 74.7 & 74.7 & 71.7 \\
\hline & Conclusion & \multicolumn{2}{|c|}{ Listeria spp. present } & \multicolumn{2}{|c|}{ Listeria spp. present } & \multicolumn{2}{|c|}{ Below LOD } & \multicolumn{2}{|c|}{ Below LOD } \\
\hline & $\begin{array}{l}\text { Average } C_{\mathrm{q}} \\
\text { St dev } C_{\mathrm{q}}\end{array}$ & \multicolumn{2}{|c|}{$\begin{array}{l}22.83 \\
0.78\end{array}$} & & & \multicolumn{2}{|c|}{ na } & & \\
\hline \multirow[t]{4}{*}{ L. seeligeri } & $C_{\mathrm{q}}$ & 26.73 & 26.09 & 25.02 & 25.48 & 34.72 & 37.91 & Und & Und \\
\hline & $T_{\mathrm{m}}$ & 75.9 & 75.9 & 71.7 & 71.7 & 74.1 & 74.1 & 73 & 72.1 \\
\hline & Conclusion & \multicolumn{2}{|c|}{ Listeria spp. present } & \multicolumn{2}{|c|}{ Listeria spp. present } & \multicolumn{2}{|c|}{ Below LOD } & \multicolumn{2}{|c|}{ Below LOD } \\
\hline & $\begin{array}{l}\text { Average } \mathrm{Cq} \\
\text { St } \operatorname{dev} C_{\mathrm{q}}\end{array}$ & \multicolumn{2}{|c|}{$\begin{array}{l}25.83 \\
0.74\end{array}$} & & & \multicolumn{2}{|c|}{ na } & & \\
\hline \multirow[t]{3}{*}{ L. grayi } & $C_{\mathrm{q}}$ & Und & 35.02 & 34.17 & Und & Und & 35.86 & Und & Und \\
\hline & $T_{\mathrm{m}}$ & 70 & 74.4 & 71.5 & 71.7 & 74.4 & 74.4 & 70 & 70 \\
\hline & Conclusion & \multicolumn{2}{|c|}{ Below LOD } & \multicolumn{2}{|c|}{ Below LOD } & \multicolumn{2}{|c|}{ Below LOD } & \multicolumn{2}{|c|}{ Below LOD } \\
\hline
\end{tabular}


the golden standard for GMO detection in food and feed (Marmiroli et al. 2008). The evaluation of these performance criteria, according to these two guidelines, showed that the four developed SYBR ${ }^{\circledR}$ Green qPCR assays, iap-50-deg, prs2-deg (for Listeria spp. (except L. grayi) detection) and hlyA177, hlyA-146-deg-tronc (for L. monocytogenes detection), are highly accurate for their targets with 98.08 and $100 \%$ accuracy, respectively. These assays are also very sensitive, with LOD between two and five copies per reaction (LOD should be between one to ten copies (Anonymous 2011b)). They are also efficient, with PCR efficiency between 97 and $107 \%$. They are repeatable, with $\mathrm{RSD}_{\mathrm{r}}$ values far below the requested $25 \%$, and they are reproducible, with $\mathrm{RSD}_{\mathrm{R}}$ values also far below the requested $35 \%$.

Besides the lack of performance criteria for qPCR in food microbiology, the qPCR assays to detect foodborne pathogens described so far are designed using different methodologies (classical PCR, real-time PCR using the TaqMan ${ }^{\circledR}$ or SYBR ${ }^{\circledR}$ Green chemistry) as well as different PCR programmes and protocols. This makes the simultaneous use of all of these methods impossible. However, such a simultaneous detection may turn out to be extremely useful when a more global approach is necessary or when a rapid identification of the foodborne pathogens is requested in a bio-emergency or outbreaks of unknown origin.

The four SYBR ${ }^{\circledR}$ Green assays were developed to be run using the same PCR programme. They can be assembled on a single plate in order to save time and reduce plate-to-plate variation. The combination of these four assays, based on two levels of detection, results in a high-quality screening system and a remarkable food surveillance tool. This qPCR system will give an answer on the presence/absence of Listeria ssp. in the sample and will at the same time indicate if the detected Listeria is L. monocytogenes which is the strain mandatory in EU regulation 2073/2005 (Anonymous 2005). The detection of other Listeria species may be useful to uncover other origins of contamination by the Listeria genus as few cases of listeriosis have been attributed to L. ivanovii (Cummins et al. 1994; Guillet et al. 2010; Lessing et al. 1994), L. innocua (Perrin et al. 2003) and L. seeligeri (Rocourt et al. 1986). Moreover, the post-amplification dissociation curve, a tool inherent to SYBR ${ }^{\circledR}$ Green chemistry, will give information about the specificity of the amplicon, further reducing false positive conclusions as well as giving information about the species or the serotypes amplified (Table 2). A similar qPCR detection system that detects both $L$. monocytogenes and the other Listeria species simultaneously is already available (Pall GeneDisc ${ }^{\circledR}$ Listeria DUO) (http://www.pall.be/pdfs/ Biopharmaceuticals/nexidia listeria id genesystems aoac 2009-v2.pdf). However, contrary to the CoSYPS Path Food system, this commercial kit is not modular. Indeed the CoSYPS Path Food system could be easily adapted to target other important foodborne pathogens such as Salmonella spp.,
Campylobacter spp. or verotoxin-producing Escherichia coli using the same screening platform. The detection assays will be added to or removed from the screening system in function of the bacteria sought in the sample. A future study will focus on the validation of the present qPCR system compared with the ISO reference method (microbiological methods) (Anonymous 1996a) on food samples according to ISO 16140 (Anonymous 2003).

Acknowledgments The authors would like to greatly thank all the laboratories that provided the strains. This project was funded by an Ylieff grant from the Belgian Federal Public Service: Public Health, Food Chain Safety and Environment. Sequencing reactions were run on an ABI 3130xl at the Platform Biotechnology and Molecular Biology at the Scientific Institute of Public Health. The authors would like to greatly thank Alexandra Duarte who performed the reproducibility analyses in the Food Pathogens Laboratories of the ISP-WIV.

Open Access This article is distributed under the terms of the Creative Commons Attribution License which permits any use, distribution, and reproduction in any medium, provided the original author(s) and the source are credited.

\section{References}

Amagliani G, Brandi G, Omiccioli E, Casiere A, Bruce J, Magnani M (2004) Direct detection of Listeria monocytogenes from milk by magnetic based DNA isolation and PCR. Food Microbiol 21:597603. doi:10.1016/j.fm.2003.10.008

Anonymous (1993) ISO norm 3534-1:1993 Statitics—vocabulary and symbols - part 1

Anonymous (1996a) ISO norm 11290-1:1996 Microbiologie des aliments-Méthode horizontale pour la recherche et le dénombrement de Listeria monocytogenes-Partie 1: Méthode de recherche

Anonymous (1996b) ISO norm 11290-2:1996 Microbiologie des aliments-Méthode horizontale pour la recherche et le dénombrement de Listeria monocytogenes-Partie 2: Méthode de dénombrement

Anonymous (2001) Risk assessment of Salmonella spp. in eggs and broiler chickens and Listeria monocytogenes in ready-to-eat food. FAO-WHO

Anonymous (2003) ISO norm 16140:2003 Microbiologie des aliments -Protocole pour la validation des méthodes alternatives

Anonymous (2005) Règlement (CE) No 2073/2005 de la Commission du 15 novembre 2005 concernant les critères microbiologiques applicables aux denrées alimentaires. European Commission

Anonymous (2008a) Definition of minimum performance requirements for analytical methods of GMO testing. European Network of GMO Laboratories

Anonymous (2008b) Evaluation of measurement data-guide to the expression of uncertainty in measurement. Joint Committee for Guides in Metrology

Anonymous (2011a) The European Union summary report on trends and sources of zoonoses, zoonotic agents and food-borne outbreaks in 2009. EFSA J 9, 2090

Anonymous (2011b) ISO norm 22118:2011 Microbiology of food and animal feeding stuffs - polymerase chain reaction (PCR) for the detection and quantification of food-borne pathogens-performance characteristics of molecular detection methods 
Anonymous (2011c) ISO norm 22119:2011 Microbiolgy of food and animal feeding stuffs - real-time polymerase chain reaction (PCR) for the detection of food-borne pathogens - general requirements and definitions

Bajard S, Rosso L, Fardel G, Flandrois JP (1996) The particular behaviour of Listeria monocytogenes under sub-optimal conditions. Int J Food Microbiol 29:201-211

Barbau-Piednoir E, Lievens A, Mbongolo-Mbella G, Roosens N, Sneyers M, Leunda-Casi A, Van den Bulcke M (2010) SYBR ${ }^{\circledR}$ Green qPCR screening methods for the presence of "35S promoter" and "NOS terminator"elements in food and feed products. Eur Food Res Technol 230:383-393. doi:10.1007/s00217-009-1170-5

Berrada H, Soriano JM, Pico Y, Manes J (2006) Quantification of Listeria monocytogenes in salads by real time quantitative PCR. Int J Food Microbiol 107:202-206

Bustin SA (2000) Absolute quantification of mRNA using real-time reverse transcription polymerase chain reaction assays. J Mol Endocrinol 25:169-193

Cardoen S, Van Huffel X, Berkvens D, Quoilin S, Ducoffre G, Saegerman C, Speybroeck N, Imberechts H, Herman L, Ducatelle R, Dierick K (2009) Evidence-based semiquantitative methodology for prioritization of foodborne zoonoses. Foodborne Pathog Dis 6:1083-1096. doi:10.1089/fpd.2009.0291

Cummins AJ, Fielding AK, McLauchlin J (1994) Listeria ivanovii infection in a patient with AIDS. J Infect 28:89-91

de Valk H, Vaillant V, Jacquet C, Rocourt J, Le Monnier A, Stainer F, Quelquejeu N, Pierre O, Pierre V, Desenclos J C, Goulet V (2001) Two consecutive nationwide outbreaks of Listeriosis in France, October 1999-February 2000. Am J Epidemio 154:944-950

de Valk, H, Jacquet C, Goulet V, Vaillant V, Perra A, Simon F, Desenclos J C, Martin P (2005) Surveillance of listeria infections in Europe. Euro Surveill 10:251-255

Dussurget O, Pizarro-Cerda J, Cossart P (2004) Molecular determinants of Listeria monocytogenes virulence. Annu Rev Microbiol 58:587-610. doi:10.1146/annurev.micro.57.030502.090934

Farber JM, Peterkin PI (1991) Listeria monocytogenes, a food-borne pathogen. Microbiol Rev 55:476-511

Garrity GM, Bell JA, Lilburn TG (2004) Taxonomic outline of the prokaryotes. Bergey's manual of systematic bacteriology, 2nd edn. Springer, New York

Gasanov U, Hughes D, Hansbro PM (2005) Methods for the isolation and identification of Listeria spp. and Listeria monocytogenes: a review. FEMS Microbiol Rev 29:851-875

Glaser P, Frangeul L, Buchrieser C, Rusniok C, Amend A, Baquero F, Berche P, Bloecker H, Brandt P, Chakraborty T, Charbit A, Chetouani F, Couve E, de DA, Dehoux P, Domann E, Dominguez-Bernal G, Duchaud E, Durant L, Dussurget O, Entian KD, Fsihi H, Garcia-del PF, Garrido P, Gautier L, Goebel W, Gomez-Lopez N, Hain T, Hauf J, Jackson D, Jones LM, Kaerst U, Kreft J, Kuhn M, Kunst F, Kurapkat G, Madueno E, Maitournam A, Vicente JM, Ng E, Nedjari H, Nordsiek G, Novella S, de Pablos B, Perez-Diaz JC, Purcell R, Remmel B, Rose M, Schlueter T, Simoes N., Tierrez A, Vazquez-Boland J A, Voss H, Wehland J, Cossart P (2001) Comparative genomics of Listeria species. Science 294:849-852

Graves LM, Helsel LO, Steigerwalt AG, Morey RE, Daneshvar MI, Roof SE, Orsi RH, Fortes ED, Milillo SR, den Bakker HC, Wiedmann M, Swaminathan B, Sauders BD (2010) Listeria marthii sp. nov., isolated from the natural environment, Finger Lakes National Forest. Int J Syst Evol Microbiol 60:1280-1288

Guillet C, Join-Lambert O, Le MA, Leclercq A, Mechai F, MamzerBruneel MF, Bielecka MK, Scortti M, Disson O, Berche P, Vazquez-Boland J, Lortholary O, Lecuit M (2010) Human listeriosis caused by Listeria ivanovii. Emerg Infect Dis 16:136-138

Hough AJ, Harbison SA, Savill MG, Melton LD, Fletcher G (2002) Rapid enumeration of Listeria monocytogenes in artificially contaminated cabbage using real-time polymerase chain reaction. J Food Prot 65:1329-1332

Inoue S, Nakama A, Arai Y, Kokubo Y, Maruyama T, Saito A, Yoshida T, Terao M, Yamamoto S, Kumagai S (2000) Prevalence and contamination levels of Listeria monocytogenes in retail foods in Japan. Int J Food Microbiol 59:73-77

Jung YS, Frank JF, Brackett RE, Chen J (2003) Polymerase chain reaction detection of Listeria monocytogenes on frankfurters using oligonucleotide primers targeting the genes encoding internalin AB. J Food Prot 66:237-241

Kerouanton A, Marault M, Petit L, Grout J, Dao TT \& Brisabois A (2009) Evaluation of a multiplex PCR assay as an alternative method for Listeria monocytogenes serotyping. J. Microbiol. Methods

Klein PG, Juneja VK (1997) Sensitive detection of viable Listeria monocytogenes by reverse transcription-PCR. Appl Environ Microbiol 63:4441-4448

Kuhn M, Goebel W (1989) Identification of an extracellular protein of Listeria monocytogenes possibly involved in intracellular uptake by mammalian cells. Infect Immun 57:55-61

Leclercq A, Clermont D, Bizet C, Grimont PA, Le Fleche-Mateos A, Roche SM, Buchrieser C, Cadet-Daniel V, Le MA, Lecuit M, Allerberger F (2010) Listeria rocourtiae sp. nov. Int J Syst Evol Microbiol 60:2210-2214

Lessing MP, Curtis GD, Bowler IC (1994) Listeria ivanovii infection. J Infect 29:230-231

Li X, Boudjellab N, Zhao X (2000) Combined PCR and slot blot assay for detection of Salmonella and Listeria monocytogenes. Int J Food Microbiol 56:167-177

Liu D, Ainsworth AJ, Austin FW, Lawrence ML (2004) Use of PCR primers derived from a putative transcriptional regulator gene for species-specific determination of Listeria monocytogenes. Int $\mathrm{J}$ Food Microbiol 91:297-304

Maijala R, Lyytikainen O, Autio T, Aalto T, Haavisto L, HonkanenBuzalski T (2001) Exposure of Listeria monocytogenes within an epidemic caused by butter in Finland. Int J Food Microbiol 70:97-109

Makino SI, Kawamoto K, Takeshi K, Okada Y, Yamasaki M, Yamamoto S, Igimi S (2005) An outbreak of food-borne listeriosis due to cheese in Japan, during 2001. Int J Food Microbiol 104:189-196

Marmiroli N, Maestri E, Gulli M, Malcevschi A, Peano C, Bordoni R, De BG (2008) Methods for detection of GMOs in food and feed. Anal Bioanal Chem 392:369-384

McLauchlin J, Mitchell RT, Smerdon WJ, Jewell K (2004) Listeria monocytogenes and listeriosis: a review of hazard characterisation for use in microbiological risk assessment of foods. Int J Food Microbiol 92:15-33

Mohr PJ, Taylor BN, Newell DB (2008) CODATA recommended values of the fundamental physical constants: 2006. Rev Mod Phys 80:633

Mukhopadhyay A, Mukhopadhyay UK (2007) Novel multiplex PCR approaches for the simultaneous detection of human pathogens: Escherichia coli 0157:H7 and Listeria monocytogenes. J Microbiol Methods 68:193-200

Nogva HK, Rudi K, Naterstad K, Holck A, Lillehaug D (2000) Application of 5 -nuclease PCR for quantitative detection of Listeria monocytogenes in pure cultures, water, skim milk, and unpasteurized whole milk. Appl Environ Microbiol 66:42664271

Norrung B, Andersen JK, Schlundt J (1999) Incidence and control of Listeria monocytogenes in foods in Denmark. Int J Food Microbiol 53:195-203

O'Grady J, Sedano-Balbas S, Maher M, Smith T, Barry T (2008) Rapid real-time PCR detection of Listeria monocytogenes in enriched food samples based on the ssrA gene, a novel diagnostic target. Food Microbiol 25:75-84 
Oravcova K, Kaclikova E, Krascsenicsova K, Pangallo D, Brezna B, Siekel P, Kuchta T (2006) Detection and quantification of Listeria monocytogenes by 5 '-nuclease polymerase chain reaction targeting the actA gene. Lett Appl Microbiol 42:15-18

Oravcova K, Kuchta T, Kaclikova E (2007) A novel real-time PCRbased method for the detection of Listeria monocytogenes in food. Lett Appl Microbiol 45:568-573

Pan Y, Breidt F Jr (2007) Enumeration of viable Listeria monocytogenes cells by real-time PCR with propidium monoazide and ethidium monoazide in the presence of dead cells. Appl Environ Microbiol 73:8028-8031

Perrin M, Bemer M, Delamare C (2003) Fatal case of Listeria innocua bacteremia. J Clin Microbiol 41:5308-5309

Postollec F, Falentin H, Pavan S, Combrisson J, Sohier D (2011) Recent advances in quantitative PCR (qPCR) applications in food microbiology. Food Microbiol 28:848-861

Rice P, Longden I, Bleasby A (2000) EMBOSS: the European Molecular Biology Open Software Suite. Trends Genet 16:276277

Rocourt J, Hof H, Schrettenbrunner A, Malinverni R, Bille J (1986) Acute purulent Listeria seeligeri meningitis in an immunocompetent adult. Schweiz Med Wochenschr 116:248-251

Rocourt J, Jacquet C, Reilly A (2000) Epidemiology of human listeriosis and seafoods. Int J Food Microbiol 62:197-209

Rossmanith P, Krassnig M, Wagner M, Hein I (2006) Detection of Listeria monocytogenes in food using a combined enrichment/ real-time PCR method targeting the prfA gene. Res Microbiol 157:763-771. doi:10.1016/j.resmic.2006.03.003

Rozen S, Skaletsky H (2000) Primer 3 on the WWW for general users and for biologist programmers. Meth Mol Biol 132:365-386

Rudi K, Naterstad K, Dromtorp SM, Holo H (2005) Detection of viable and dead Listeria monocytogenes on gouda-like cheeses by realtime PCR. Lett Appl Microbiol 40:301-306

Rutledge RG, Cote C (2003) Mathematics of quantitative kinetic PCR and the application of standard curves. Nucleic Acids Res 31:e93

Sarachu M, Colet M (2005) wEMBOSS: a web interface for EMBOSS. Bioinformatics 21:540-541

Schmid MW, Ng EY, Lampidis R, Emmerth M, Walcher M, Kreft J, Goebel W, Wagner M, Schleifer KH (2005) Evolutionary history of the genus Listeria and its virulence genes. Syst Appl Microbiol 28:1-18

Tham W, Ericsson H, Loncarevic S, Unnerstad H, Nielsson-Tham ML (2000) Lessons from an outbreak of listeriosis related to vacuumpacked gravad and cold-smoked fish. Int J Food Microbiol 62:173-175

Thulin Hedberg S, Olcen P, Fredlund H, Molling P (2009) Real-time PCR detection of five prevalent bacteria causing acute meningitis. APMIS 117:856-860

Winters DK, Maloney TP, Johnson MG (1999) Rapid detection of Listeria monocytogenes by a PCR assay specific for an aminopeptidase. Mol Cell Probes 13:127-131 